\title{
KOMODIFIKASI TATA PAMER DALAM UPAYA PREVENTIF
}

\author{
Vandrowis Darwis \\ Museum Adityawarman \\ Vandrowis@yahoo.com
}

\begin{abstract}
ABSTRAK
Fenomena komodifikasi tidak dapat dihindari dalam sektor pariwisata dan budaya termasuk museum. Sebagai institusi budaya, museum terus mengalami perubahan dalam pengelolaan koleksi. Penelitian ini mencoba melakukan proses komodifikasi tata pamer di Museum Adityawarman di Kota Padang khususnya penyajian koleksi di dalam vitrin (showcase) dan lingkungan mikro. Kondisi suhu dan kelembaban di Kota Padang selalu mengalami perubahan dan tentunya menggangu proses pelestarian koleksi di ruang pamer. Upaya preventif tentu dilakukan tanpa menggurangi estetika dan kemampuan vitrin dalam pendukung penyajian koleksi di ruang pamer, tindakan preventif tidak hanya pada suhu dan kelembaban tapi juga terhadap agen perusak lainnya, proses komodifikasi seperti apa yang tepat untuk dilakukan diruang pamer museum.
\end{abstract}

Kata Kunci: Komodifikasi; preventif; vitrin; koleksi

\section{ABSTRACT}

The phenomenon of commodification cannot be avoided in the tourism and cultural sector, including museums. As a cultural institution, the museum continues to experience changes in its collection management. This research tries to modify the exhibition system at the Adityawarman Museum in Padang City, especially the presentation of collections in vitrine (showcase) and the micro environment. The temperature and humidity conditions in the city of Padang are always changing and of course disrupt the process of preserving the collection in the exhibition room. Preventive efforts are certainly carried out without reducing the aesthetics and vitrin abilities in supporting the presentation of collections in the exhibition room, preventive measures not only on temperature and humidity but also against other destructive agents, what kind of commodification process is appropriate to do in the exhibition museum.

Keywords: Comodification; preventive; vitrine; collection

\section{PENDAHULUAN}

Perubahan paradigma dan perkembangan peran museum membuat museum menyadari pentingnya untuk memberi perhatian terhadap apa yang menjadi kebutuhan pengunjung museum saat ini dan masyarakat yang berpotensi menjadi pengunjung museum. Oleh karena itu museum seharusnya memasukkan metode dan strategi yang lebih baik dalam pengelolaan museumnya dengan cara tidak biasa. Museum memiliki potensi tinggi sebagai daya tarik wisata, namun permasalahan museum sering hanya ditempatkan dalam posisi yang tak berbeda dengan art shop atau gallery, indah tetapi kurang informatif. Walaupun koleksinya cukup memadai, namun tampilan dan penyajian kurang terkonsep membuatnya tidak mampu membangun ikatan emosional dengan pengunjung.

Selain fungsi budaya, museum sebagai penguat identitas bangsa dan yang lebih penting museum sebenarnya memiliki potensi ekonomi. Pendapatan yang diperoleh dari penjualan karcis pengunjung seharusnya mampu membantu operasional museum lebih baik, menurut Aegeson (1999) upaya menampilkan museum menjadi unik karena fungsi utama museum untuk edukasi publik harus sepadan dengan upaya menarik pengunjung dan menghasilkan revenue.

Museum Adityawarman merupakan salah satu Museum Negeri milik Pemerintah Provinsi Sumatera Barat, Museum Adityawarman secara geografis terletak kurang lebih 200 
meter dari bibir pantai barat Pulau Sumatera dan berada di pusat jantung ibukota Provinsi Sumatera Barat yaitu Kota Padang. Sebagai etalase kebudayaan di wilayah Sumatera Barat, museum harus bisa menampilkan gambaran budaya di Sumatera Barat kepada masyarakat dunia. Dalam Chen, Mak, dan Li (2013) menyebutkan peran penting citra museum untuk membangun persepsi kualitas layanan, pengelola museum perlu membangun kembali citra negatif museum menjadi positif dilingkungannya. Museum yang sering dicitrakan dengan istilah "kuno, tua, kotor, berdebu, dan panas" secara perlahan perlu digeser menjadi "modern, muda, bersih, dan dingin".

Sebagai sarana rekreasi, museum merupakan pusat informasi dan sarana yang bersifat edukatif bagi masyarakat. Pengunjung diharapkan mendapatkan pengetahuan melalui koleksi-koleksi yang dihadirkan di dalam museum dengan suasana ruang yang nyaman. Aspek tata pamer menjadi salah satu peran penting dalam memberikan kenyamanan kepada pengunjung, ada hal lain yang lebih penting lagi karena museum memiliki tugas sebagai pelestari kebudayaan yaitu penyelamatan koleksi, koleksi yang disimpan atau dipamerkan merupakan benda budaya dan bersejarah yang memerlukan perhatian khusus, tidak hanya vitrin yang baik untuk melindungi koleksi tetapi bagaimana kondisinya aman di ruang pamer.

Bangunan utama Museum Adityawarman sebagai ruang pamer menyerupai rumah adat suku Minangkabau, rumah gadang menjadi ciri khas rumah adat suku Minangkabau di daerah Sumatera Barat, bentuk unik bangunan dengan gonjong di bagian atas menjadi ikon unik Museum. Upaya memperbaharui interior untuk ruang pamer museum telah beberapa kali dilakukan dalam sepuluh tahun terakhir, pertama ketika gempa pada tahun 2009 di Kota Padang dengan melakukan penguatan terhadap tiang-tiang beton yang ada di ruang pamer pada tahun 2010, kedua tahun 2011 dengan menukar lantai keramik dengan ukuran yang lebih besar termasuk penambahan plafond di bagian timur ruang pamer dan pembaharuan berbagai vitrin, dan terakhir tahun 2020 dengan menambahkan kaca pada jendela dengan alasan faktor kondisi alam.

Dengan dilakukan beberapa pembaharuan ruang pamer tersebut perlu dilakukan penelitan untuk melihat efektivitas ruang pamer dalam sudut komodifikasi tata pameran yang baik sebagai upaya preventif terhadap koleksi yang disajikan. Penelitian terbatas pada komodifikasi tata pamer serta tingkat kelembaban, lingkungan ruang, dan suhu vitrin sebagai gambaran kondisi terkini dan menjadi ukuran dalam melakukan tindakan pencegahan dan upaya meningkatkan kenyamanan pengunjung.

\section{TUJUAN}

Tujuan dari penelitian komodifikasi tata pamer dalam upaya preventif sebagai cara mengetahui proses komodifikasi yang terjadi di ruang pamer Museum Adityawarman dalam melakukan pelindungan koleksi dan menjaga kondisi ruang pengunjung yang representative sebagai alternatif referensi dalam pengembangan ruang pamer museum.

\section{LANDASAN TEORI}

Landasan teori untuk dapat menyampaikan konsep, teori atau referensi hasil penelitian yang ada untuk digunakan pada kajian komodifikasi tata pamer dalam upaya preventif di Museum Adityawarman. Konsep yang disampaikan mengenai Komodifikasi, Tata Pamer Museum, dan Preventif. 


\section{Komodifikasi}

Konsep komodifikasi dipengaruhi oleh perspektif Marxisme, dalam prespektif tersebut komodifikasi dipandang sebagai alat dari kapitalis untuk meraih keuntungan sebesarnya dengan menghisap nilai surplus dan menghasilkan materi atau sesuatu yang mengandung nilai guna dan nilai tukar yang disebut "komoditas" (Barker, 2009). Dasar semua karya Marx tentang struktur sosial dan tempat dimana karya-karya tersebut sangat jelas berhubungan dengan pandangan-pandangannya tentang produk kerja terutama dimaksudkan untuk dipertukarkan. Sebagaimana yang diungkapkan oleh George Lukas, "persoalan komoditi adalah pusat persoalan kultur masyarakat kapitalis". Dengan memulai komoditas, Marx mampu mengungkap hakikat kapitalisme.

Komodifikasi proses yang diasosiasikan dengan kapitalisme, di mana objek, kualitas, dan tanda-tanda diubah menjadi komoditas, yaitu sesuatu yang tujuan utamanya untuk dijual di pasar (Barker, 2005: 517). Komodifikasi adalah proses karya seni baik abstrak maupun konkrit yang sebelumnya sebagai karya sakral untuk persembahan. Dengan kesadaran penuh dan perhitungan yang matang dari seniman maupun konsumen, diproduksi untuk memenuhi kebutuhan pasar dan diperjualbelikan kepada masyarakat yang membutuhkan karya seni tersebut (Tester, 2009: 84).

Prinsip dasar komodifikasi yang merambat pada bidang kebudayaan adalah tradisi atau budaya menjadi patuh kepada hukum komoditi kapitalisme. Berdasarkan beberapa pengertian tersebut, komodifikasi pada kajian ini ingin mengungkap bentuk komodifikasi tata pamer di Museum Adityawarman sekaligus menjelaskan bahwa tata pamer adalah salah satu komoditi yang diproduksi, didistribusikan, dan dikonsumsi untuk tujuan-tujuan komersial serta fungsi ekonomi lainnya. Dengan demikian komodifikasi secara operasional adalah sebuah proses dalam upaya pengelola museum menjadikan penataan ruang pameran yang memiliki nilai jual, rebranding, dan lebih baik dalam memberikan peluang dalam meningkatkan pengunjung dan memanfaatkan museum sebagai pengetahuan budaya dan sejarah sekaligus sebagai sarana wisata budaya di Sumatera Barat.

\section{Tata Pamer Museum}

Menurut Kamus Besar Bahasa Indonesia, kata "tata" /ta.ta (n) adalah aturan atau susunan; me.nata ( $v$ ) mengatur; menyusun; dan membenahi (Qodratilah, 2011:522). Kata tata yang dimaksud yaitu tata pamer yang dilakukan di museum dengan membuat susunan koleksi dengan cara menata atau menyajikan koleksi di ruang pameran. Menata koleksi adalah cara bagaimana seni menata atau menyusun koleksi yang tersaji di ruang pamer, dari tata pamer bisa melahirkan pameran untuk dapat tersampaikan informasi yang diharapkan kepada pengunjung.

Banyak alasan kenapa koleksi harus ditata dengan baik di ruang pamer, salah satunya koleksi museum adalah benda-benda yang dikumpulkan memiliki nilai sejarah dan budaya yang harus diberi perhatian lebih. Benda-benda warisan budaya ini ada yang sudah tidak di produksi lagi di masyarakat atau bahkan tidak ada duanya di dunia, karena hal tersebut perlu diselamatkan dan dilestarikan. Benda koleksi membawa pesan, makna, dan manfaat untuk dapat dilanjutkan informasinya untuk masa kini dan masa depan, menyimpan koleksi di ruang pamer tentunya harus diperhitungan dengan keselamatan koleksi tersebut karena berada di ruang publik, sedikit perlu upaya lebih dalam penataannya tidak hanya sekedar estetika saja. Upaya penataan dan mengoleksi benda koleksi pada manusia sudah hal mendasar yang dilakukan, manusia telah melakukan kegiatan mengoleksi dan penyimpanan 
benda-benda yang dianggap penting sejak dahulu. Namun belum dilakukan di sebuah insititusi atau bangunan khusus (yang saat ini dikenal dengan museum), melainkan di tempattempat yang di anggap penting dan sakral seperti kuil (Asia) dan gereja (Eropa), serta menunjuk seseorang sebagai penjaga barang-barang tersebut (Wulandari, 2014:247).

Museum menurut The Museums Association (United Kingdom) 'A museum is an institution which collects, documents, preserves, exhibits and interprets material evidence and associated information for the public benefit' (dalam Ambrose \& Paine, 1993:8). Ambrose dan Paine menjelaskan bahwa museum modern seperti yang dikenal sekarang muncul pertama kali di Eropa pada abad ke-17. Sedangkan istilah museum pertama kali digunakan pada 1682 untuk menjelaskan sebuah koleksi barang-barang yang aneh, langka, dan eksotik yang diberikan kepada University of Oxford oleh Elias Ashmole sekarang dikenal dengan Museum Ashmolean (Wulandari, 2014:247).

Tata pamer koleksi di museum adalah bagian besar tugas pengelola museum yang cukup rumit untuk dikerjakan, tata pamer sebagai media komunikasi perlu dipertimbangkan gagasan apa yang ingin disampaikan kurator terhadap masyarakat, menurut Herle A, (2016:2) prinsip pengumpulan, klasifikasi, dan pameran koleksi museum telah lama memengaruhi cara-cara mengetahui bagaimana manusia terbentuk. Dari abad keenam belas, penjelajah Eropa mengumpulkan benda alam dan 'buatan' untuk keingintahuan sebagai sarana mencoba memahami keanekaragaman dunia dan masyarakatnya, koleksi dikumpulkan sebagai piala petualangan dan penaklukan daerah yang jauh. Awalnya koleksi ditampilkan di istana dan kemudian diatur dalam lemari pajangan untuk keingintahuan para petualang lainnya, koleksi disusun dengan bahan yang beragam dimaksudkan untuk memberikan wawasan tentang tatanan alam dan dunia manusia (Herle A, 2016:3).

Proses penataan dan penyajian koleksi museum harus melalui sebuah kajian matang dan juga perencanaan yang baik, dengan berlandaskan pada tiga pilar kebijakan permuseuman khususnya di Indonesia, yaitu pertama mencerdaskan bangsa; kedua kepribadian bangsa; dan ketiga ketahanan nasional dan wawasan nusantara (Thahjopurnomo, 2011:22). Untuk memperoleh hasil maksimal dalam tata pamer perlu diketahui lebih dulu faktor utama pameran museum, menurut Sutaarga, M. Amir (1997:64) pertama pengunjung museum, kedua kebijakan dan perencanaan, dan ketiga metode penyajian. Setelah faktor utama ini sudah dipahami oleh pengelola atau kurator museum, maka menurut Sutaarga masuk kepada metode penyajian yang disesuaikan dengan motivasi atau target pengunjung, yakni dengan menggunakan secara terpadu. Pertama metode estetik, untuk meningkatkan penghayatan terhadap nilai-nilai artistik dari warisan budaya atau koleksi yang tersedia; kedua metode tematik atau metode intelektual dalam penyebarluasan informasi tentang guna, arti, dan fungsi koleksi museum; dan ketiga metode romantik untuk menggugah suasana dan kenyataan-kenyataan sosial-budaya di antara berbagai suku bangsa (Sutaarga, 1997:67).

Penataan pameran pada masa-masa sebelumnya menurut Sutaarga (1997:70) menempati bangunan monumental mirip istana yang memiliki ruang yang luas dan besar, sehingga semua koleksi bisa ditampilkan lebih banyak, bahkan lukisan bukan saja dipasang berjajar, tetapi juga bertingkat sehingga seluruh dinding penuh dengan lukisan. Museum etnografi misalnya dipenuhi koleksi ethnografika, baik setiap dinding dan setiap sudut ruangan, maupun dalam lemari- lemari pameran, berjejal-sesak dengan benda-benda yang dipamerkan. Kesemuanya itu memang secara pendekatan intelektual memenuhi keinginankeinginan akademis serba lengkap, serba sistematis, dan serba ketat. Tetapi secara estetis dan informatif teknik pameran seperti suasana gudang, sehingga menurut Sutaarga pada saat sekarang ini sudah tidak dapat dibenarkan menampilkan semua koleksi di ruang yang terbatas.

Tata pameran museum sudah tidak pas hanya mengandalkan panel dan vitrin (lemari pajangan/Furnitur) yang sudah ada atau bahkan sisa pameran sebelumnya, walaupun dengan 
berbagai model vitrin standar yang ada seperti vitrin tunggal, vitrin ganda, atau model vitrin dinding, vitrin tengah, dan sudut yang semua multi fungsi. Pengertian vitrin pada ruang pamer adalah sarana peraga atau perabot atau benda peraga atau sarana pamer untuk benda koleksi museum. Konsep dasar rancangan mengacu pada konsep pelindungan, konservasi, dan pengamanan benda koleksi pamer. Berdasarkan konsep di atas maka jenis vitrin/furniturperabot peraga antara lain adalah: vitrin lepas terbuka dan tertutup transparan; vitrin dinding terbuka dan tertutup transparan; box terbuka dan tertutup transparan; panel-panel lepas, panel-panel dinding; dan sarana pamer lainnya.

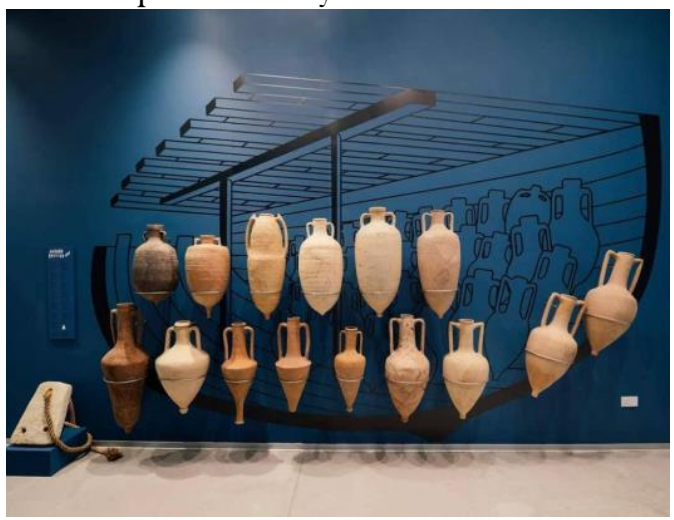

Gambar 1 : Pemanfaatan dinding panel di Paphos Archaelogical Museum, Cyprus.

(Sumber : Ig Departmen of antiquities, Cyprus)

Konsep tata letak furnitur-lemari peraga harus mengacu pada konsep alur penyajian pameran dan ukuran benda koleksi pamer, bukan sekedar alur cerita saja (Story line). Bentuk dan ukuran furnitur peraga ditentukan oleh skala, besaran, dan ruang gerak benda koleksi pamer dan ruang gerak perawatan koleksi. Bahan atau material furnitur-perabot yang akan digunakan ditentukan oleh ukuran dan persyaratan konservasi. Usulan modul yang disesuaikan dengan modul komponen lantai, dinding, dan plafon adalah modul $30 \mathrm{~cm}$, dengan kelipatan 60, 90,120, 150, 180, 210, dan 240 cm (Agung Purnomo, Basnendar Herryprilosadoso, Ranang Agung Sugihartono, 2012:11)

Banyaknya elemen yang ada di ruang pamer dalam menata sehingga tidak bisa hanya dilakukan seorang kurator tapi harus melibatkan berbagai disiplin ilmu terutama dari arsitektur dan desain komunikasi visual.

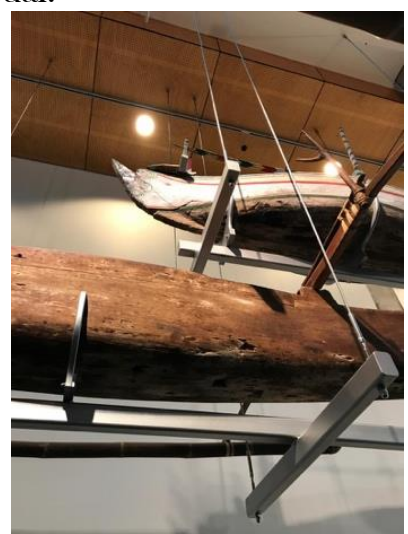

Gambar 2 : Koleksi perahu digantung di Museum Maritim Perth

(Sumber : Pribadi)

McLean (1993) menyebutkan salah satu elemen penting lainnya dalam pembentukan sebuah ruang pamer adalah harmoni atau bagaimana elemen ruang, seperti bentuk, keseimbangan, skala, proporsi, ritme, dan penekanan akan saling mendukung satu sama lain. Dalam kaitannya dengan menciptakan sebuah pameran yang menarik, Martin 
Sklar (McLean, 1993) menjelaskan mengenai Mickey’s Ten Commandments, sebuah filosofi di balik pendekatan Disney dalam menciptakan fasilitas rekreasi dan edukasinya, yang juga dapat diterapkan dengan sebuah pameran. Filosofi tersebut antara lain: jangan membuat pengunjung bosan dengan merendahkan mereka atau memberikan terlalu banyak informasi yang menimbulkan kebingungan, jika banyak informasi yang ingin disampaikan kelompokanlah informasi tersebut dalam susunan cerita yang logis dan terorganisasi sehingga lebih mudah diterima dan dicerna oleh pengunjung; selalu melihat segala sesuatunya dari sudut pandang pengunjung; merancang susunan cerita yang menarik dan logis karena pada kenyataannya pengunjung lebih senang diberikan cerita dibandingkan kuliah; serta berilah sebuah 'wienie' atau 'hadiah'. Walaupun hanya diberikan secara visual, 'hadiah' ini dapat membuat pengunjung bersemangat berjalan dari satu titik ke titik berikutnya (McLean, 1993).

Terlalu banyak konsep mengenai tata pamer di museum sampai persoalan tentang antropometri pengunjung pada ruang pamer juga menjadi penting, tapi karena keterbatasan ruang pada landasan teori tata pamer ini coba ditutup dengan konsep dari David Dean (1994 :67) mengenai pentingnya misi konservasi sebuah museum dalam penataan koleksi, Dean mengharuskan interaksi koleksi dengan pengunjung dan lingkungan dijaga seminimal mungkin.

Mengontrol faktor yang mendorong interaksi koleksi dalam pameran, lingkungan sekitar benda koleksi perlu dipahami sejelas mungkin oleh kurator. Untuk bisa memberikan perawatan yang memadai untuk benda-benda saat dipamerkan, faktor lingkungan harus diperhatikan dikendalikan setepat mungkin. Faktor utama yang perlu dipertimbangkan menurut Dean adalah :

- suhu

- kelembaban relatif (RH)

- bahan partikulat dan polutan

ini semua membutuhkan perhatian utama dalam semua aktivitas manajemen koleksi di ruang pameran.
- organisme biologis

- reaktivitas bahan

- cahaya

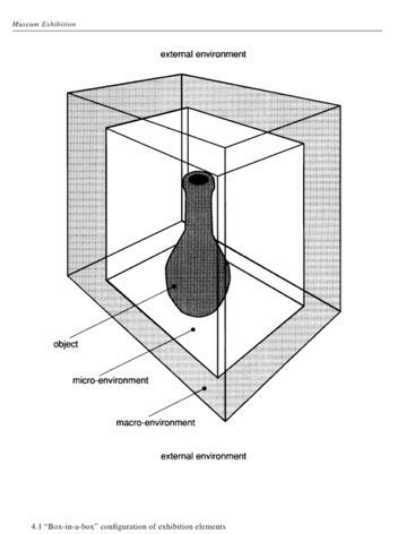

Gambar 3 : Kotak dalam kotak (Box-in-a-box) konfigurasi element pameran (Sumber : Dean, David. 1994:8)

Konsep tata pamer tersebut di atas dipadukan dengan konsep-konsep preventif terhadap koleksi sebagai batasan kajian untuk membantu melakukan komodifikasi tata pamer dalam upaya tindakan preventif di Museum Adityawarman tanpa bermaksud untuk mengabaikan unsur-unsur tata ruang pamer lainnya yang lebih kompleks.

\section{Preventif}

Preventif yang dimaksudkan adalah tindakan atau upaya untuk pemeliharaan dan mencegah kerusakan yang terjadi pada koleksi di ruang pamer. Upaya atau tindakan pemeliharaan dan pelindungan sejajar dengan pengertian konservasi yaitu sebagai suatu 
tindakan untuk melindungi dari bahaya atau kerusakan; memelihara atau merawat sesuatu dari gangguan, kemusnahan, atau keausan (Herman, 1981: 7). Jadi, preventif bagian dari konservasi, konservasi adalah kegiatan fundamental yang dapat menentukan masa depan museum serta koleksinya. Menurut International Council of Museums (ICOM), praktik atau kegiatan konservasi saat ini dapat dibedakan menjadi tiga jenis berdasarkan tujuan dan tindakan yang dilakukan yaitu konservasi preventif (preventive conservation), konservasi remedi (remedial conservation), dan restorasi (restoration). Tindakan konservasi preventif merupakan aksi paling dasar dalam praktik konservasi koleksi karena dalam pelaksanaannya tidak membutuhkan keterampilan khusus seperti seorang konservator atau restorator. Individu atau kelompok yang melakukan kegiatan konservasi preventif tidak diperbolehkan untuk memodifikasi bahan, material, dan struktur benda koleksi secara langsung karena konservasi preventif bersifat indirect (Rozaq, Saputra, Susanto.2019 :2).

Komite Konservasi Dewan Museum Internasional (ICOM CC) seperti yang dikutip Yulita dan kawan-kawan (2020:3), membuat pengelompokkan konservasi dalam tiga bagian yaitu konservasi preventif, konservasi interventif, dan restorasi, dengan definisinya sebagai berikut: Pertama konservasi preventif adalah semua pengukuran dan tindakan yang bertujuan untuk menghindari dan meminimalkan kerusakan atau kehilangan di masa depan. Kegiatan dalam konteks atau dilingkungan koleksi atau sekumpulan koleksi yang tidak membedakan usia dan kondisi koleksi. Langkah-langkah dan tindakan ini (Sebagian besar) tidak langsung mengenai koleksi dan tidak mengubah struktur koleksi. Contoh konservasi preventif di dalam museum adalah pengukuran dan tindakan yang tepat dalam penataan, penyimpanan, pengemasan, transportasi, manajemen lingkungan (cahaya, kelembapan, polusi, dan pengendalian hama) dari koleksi. Selain hal tersebut, kegiatan seperti tanggap darurat (emergency responses), pendidikan/pengetahuan kesadaran staf dan publik, merupakan konservasi preventif yang tidak langsung berhubungan dengan koleksi.

Kedua konservasi interventif adalah semua tindakan yang langsung diterapkan pada koleksi atau sekelompok koleksi yang bertujuan untuk menghentikan proses yang merusak koleksi, ataupun untuk memperkuat strukturnya. Tindakan ini hanya dilakukan ketika koleksi berada dalam kondisi rapuh atau pada kerusakan parah, dan jika dilakukan maka kondisi akan semakin memburuk dalam waktu singkat atau bahkan hilang. Contoh konservasi interventif pembersihan tekstil, desalinasi keramik, deasidifikasi kertas, dehidrasi koleksi arkeologi basah, stabilisasi logam berkarat, dan penghilangan jamur pada kayu.

Ketiga adalah restorasi, semua tindakan yang langsung diterapkan pada satu koleksi yang bertujuan untuk meningkatkan apresiasi, pemahaman, dan pemanfaatannya melalui perbaikan. Tindakan ini hanya dilakukan ketika koleksi telah kehilangan sebagian dari signifikansi atau fungsinya. Contoh restorasi adalah memperbaiki lukisan, memasang patung yang rusak, dan membentuk kembali keranjang/wadah. Terkadang satu tindakan dapat bersifat preventif, interventif, dan/atau restorasi pada saat yang sama. Hal ini menurut Yulita menunjukkan bahwa konservasi itu kompleks dan menuntut kolaborasi profesional berkualifikasi yang relevan (Yulita, Ita. dkk. 2020:3-4).

Lebih penting dalam tindakan preventif atau konservasi preventif yaitu mencegah hal-hal kecil yang sering menjadi besar seperti adanya agen/faktor penyebab deteriorasi koleksi. Komite Konservasi Dewan Museum Internasional dan Komite Konservasi Kanada menetapkan sepuluh agen/faktor penyebab deteriorasi koleksi yaitu: Gaya fisik, Pencurian/Vandalisme, Api, Air, Hama, Polutan, Cahaya Ultraviolet/inframerah, 
Temperatur yang tidak sesuai, Kelembapan relatif yang tidak sesuai, dan disosiasi. Tindakan preventif di ruang pamer tidak hanya sebatas melindungi koleksi dari agen/ faktor deteriosasi dalam vitrin saja, tapi menurut Yulita mulai dengan lapisan pelindung yang terkecil yaitu dari koleksi, tatakan, vitrin, ruangan/galeri, gedung, lokasi, dan wilayah (Yulita, Ita. dkk. 2020:9).

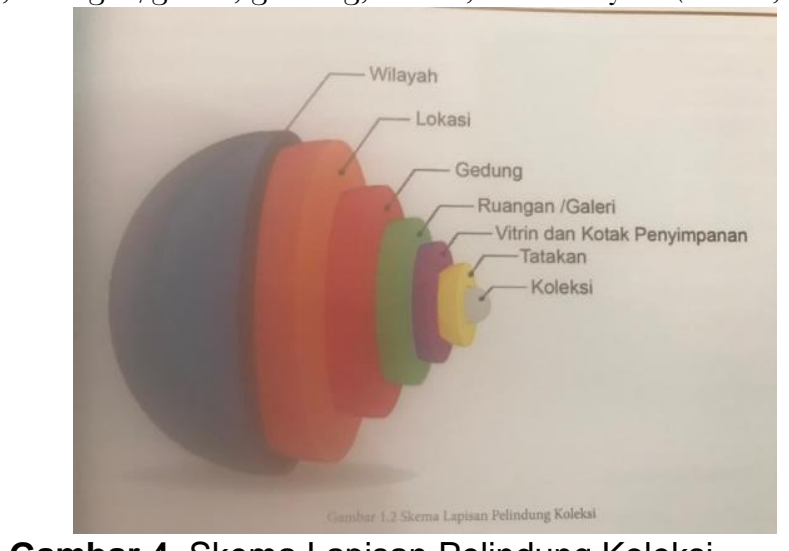

Gambar 4. Skema Lapisan Pelindung Koleksi

(Sumber : Yulita, Ita. dkk. 2020:9)

Pelindungan koleksi berdasarkan skema lapisan pelindungan koleksi menjadi lebih luas, mulai dari koleksi itu sendiri, maksudnya koleksi yang tidak layak dipamerkan maka sebaiknya di simpan di gudang seperti kondisi koleksi yang rapuh tanpa pelindung yang akan membahayakan koleksi itu sendiri, kemudian tatakan atau mounting sebagai wadah tempat menyimpan koleksi harus mendukung pelindungan koleksi. Kemudian kemampuan vitrin atau lemari pajangan sebagai pelindung pertama terhadap koleksi dan lanjut pada kondisi bangunan hingga wilayah keberadaan museum tersebut berada, apakah wilayah dalam kondisi yang aman dan baik dari perubahan iklim sampai kondisi politik (seperti kondisi perang) lokasi museum tersebut berada.

Temperatur udara permukaan di Sumatera Barat menjadi kendala bagi Museum Adityawarman selain bencana gempa, ada peningkatan temperatur dan kelembapan relatif yang tidak sesuai terhadap pelindungan koleksi khususnya di Kota Padang, telah banyak penelitian dilakukan salah satunya oleh Musyayyadah (2019: 91) dengan menggunakan data stasiun Badan Meteorologi, Klimatologi, dan Geofisika (BMKG). Untuk 11 tahun pengamatan (2007 - 2017) di empat lokasi, yaitu Teluk Bayur (Padang), Minang Kabau (batas kota Padang - Padang Pariaman), Sincincin (Padang Pariaman) dan Padang Panjang. Selain itu digunakan juga data re-analisis dari European Centre for Medium-Range Weather Forecasts Re-Analysis interim model data (ECMWF ERA-Interim) untuk 38 tahun pengamatan (1980 - 2017). Osilasi internal temperatur udara permukaan di Sumatera Barat diamati menggunakan transformasi wavelet dengan mother Maxican Hat. Hasil penelitiannya menunjukkan bahwa temperatur udara permukaan rata - rata di Sumatera Barat meningkat sekitar $0,007^{\circ} \mathrm{C}-0,01^{\circ} \mathrm{C} /$ tahun. Temperatur maksimum harian meningkat sekitar $0,058^{\circ} \mathrm{C}$ $0,066^{\circ} \mathrm{C} /$ tahun, sedangkan temperatur udara minimum harian meningkat sekitar $0,028^{\circ} \mathrm{C}-$ 0,045 ${ }^{\circ} \mathrm{C} /$ tahun (Musyayyadah, 2019: 91). Selain itu tren temperatur udara maksimum dan minimum hariannya juga mengalami peningkatan berturut-turut $0,058^{\circ} \mathrm{C} /$ tahun dan $0,028^{\circ} \mathrm{C} /$ tahun di Kota Padang, $0,066^{\circ} \mathrm{C} /$ tahun dan $0,045^{\circ} \mathrm{C} /$ tahun di Kabupaten Padang Pariaman, serta $0,063^{\circ} \mathrm{C} /$ tahun dan $0,0332^{\circ} \mathrm{C} /$ tahun di Kota Padang Panjang. Periode perulangan dominan temperatur udara permukaan di Sumatera Barat adalah 1 tahun (osilasi tahunan). Selain itu, juga terdapat osilasi 4 tahun dan 8 tahun yang menyatakan bahwa temperatur udara permukaan di wilayah pengamatan Sumatera Barat dipengaruhi oleh munson dan ENSO (Musyayyadah, 2019: 96). 
Setelah mengetahui iklim di kota Padang maka coba mereview penelitian lain untuk mengetahui kenyamanan pengunjung dalam ruang bangunan. Menurut Santoso (2012) kenyamanan termal di daerah beriklim tropis lembab untuk bangunan (indoor) dengan menggunakan penghawaan alami atau ventilasi sulit untuk menjangkau standar kenyamanan internasional ASHRAE 55- 92, karena rata-rata suhu udara dan kelembaban relatif tinggi sehingga suhu netral tidak memenuhi zona kenyamanan yang disyaratkan yaitu antara $23^{\circ} \mathrm{C}$ sampai $26^{\circ} \mathrm{C}$. Sementara dari beberapa penelitian menurut Santoso (2012) yang dilakukan oleh Nugroho (2011), Roonak et al. (2009), Henry dan Nyuk (2004), Sulaiman et al. (2011), Iftikhar et al. (2001) dan Alison (2003) di daerah beriklim tropis lembab dengan objek beberapa jenis bangunan menunjukkan suhu netral antara $26.1^{\circ} \mathrm{C}-29.8^{\circ} \mathrm{C}$. Berdasarkan beberapa penelitian sulitnya mencapai suhu netral yang sesuai zona kenyamanan termal dipengaruhi oleh beberapa faktor diantaranya karena disain banguan yang menyebabkan radiasi sinar matahari cukup tinggi (Nugroho, 2011), sirkulasi udara yang disebabkan kecepatan udara relatif kecil ( Roonak et al., 2009) dan tingginya kelembaban udara karena faktor iklim (tropis lembab) (Santoso. 2012:15)

Penelitian yang dilakukan Tiurma di Museum Nasional (2013) ada sedikit kemiripan hanya berbeda ruang, penelitian dilakukan di ruang penyimpanan yang menunjukkan betapa pentingnya preservasi terhadap koleksi. Preservasi yang dimaksudkan juga mencakup ruangan tempat meletakkan koleksi di Museum Nasional. Menurut Tiurman pengawasan berkala menghasilkan laporan untuk setiap ruangan yang dapat dimonitor dan disesuaikan untuk suhu dan kelembapannya harus dilakukan rutin, tindakan cepat untuk penyesuaian suhu dapat dilakukan dalam jangka waktu tertentu untuk memperkecil kemungkinan kerusakan koleksi. Penyesuaian suhu biasanya dilakukan dengan menempatkan air conditioner (AC), humidifier, dan pengukur suhu di setiap ruangan. (Tiurman, Aninda Renata dan Ali akbar, 2013).

\begin{tabular}{l|c|c|c|c}
$\begin{array}{c}\text { Nama } \\
\text { Ruangan }\end{array}$ & $\begin{array}{c}\text { Penguk } \\
\text { uran } \\
\text { Pertama } \\
\text { Min }\end{array}$ & $\begin{array}{c}\text { Pengukuran } \\
\text { Pertama } \\
\text { Maks }\end{array}$ & $\begin{array}{c}\text { Penguku } \\
\text { ran } \\
\text { Kedua } \\
\text { Min }\end{array}$ & $\begin{array}{c}\text { Penguku } \\
\text { ran } \\
\text { Kedua } \\
\text { Maks }\end{array}$ \\
\hline $\begin{array}{l}\text { Ruang } \\
\text { Emas }\end{array}$ & $24,3^{\circ}$ & $31,5^{\circ}$ & $25^{\circ}$ & $29,1^{\circ}$ \\
\hline $\begin{array}{l}\text { Ruang } \\
\text { Tekstil }\end{array}$ & $28,5^{\circ}$ & $30,2^{\circ}$ & $29^{\circ}$ & $31,6^{\circ}$ \\
\hline $\begin{array}{l}\text { Ruang } \\
\text { Transit }\end{array}$ & $24,3^{\circ}$ & $31^{\circ}$ & $22,3^{\circ}$ & $27,6^{\circ}$ \\
& & & &
\end{tabular}

Gambar 5. Pengukuran Suhu Ruang (Sumber : Tiurman, Anida Renata. 2013)

\begin{tabular}{l|l|l|l|l} 
Nama Ruangan & $\begin{array}{l}\text { Penguku } \\
\text { ran } \\
\text { Pertama } \\
\text { Min }\end{array}$ & $\begin{array}{l}\text { Pengu } \\
\text { kuran } \\
\text { Pertam } \\
\text { a Maks }\end{array}$ & $\begin{array}{l}\text { Pengu } \\
\text { kuran } \\
\text { Kedua } \\
\text { Min }\end{array}$ & $\begin{array}{l}\text { Pengukur } \\
\text { an Kedua } \\
\text { Maks }\end{array}$ \\
\hline Ruang Emas & $62,7 \%$ & $71,4 \%$ & $61,6 \%$ & $72,7 \%$ \\
\hline Ruang Tekstil & $66 \%$ & $93,5 \%$ & $70,3 \%$ & $99,3 \%$ \\
\hline Ruang Transit & $62,7 \%$ & $71,4 \%$ & $88 \%$ & $100 \%$ \\
\multicolumn{4}{c}{ Gambar 6. Pengukuran Kelembapan Ruang }
\end{tabular}


(Sumber : Tiurman, Anida Renata. 2013)

Dalam skala mikro di ruang pamer ada masalah materi partikulat (debu) dan polutan (bahan kimia di udara) yang menimbulkan masalah dan sering diabaikan dalam tindakan preventif, menurut Dean (1994) sebaiknya udara yang masuk harus melalui serangkaian filter sebelum masuk bangunan. Dalam beberapa kasus, memasang filter serat cukup untuk menghilangkan debu dan pasir yang masuk keruang pamer. Di lain kasus bisa dengan cara ionisasi, fumigasi ruang atau mekanisme penyaringan canggih lainnya yang diperlukan untuk menghilangkan partikel yang sangat halus dan gas yang terbawa udara.

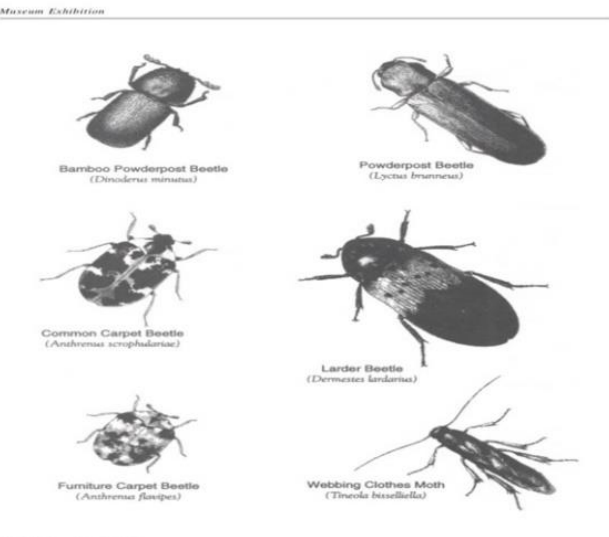

Gambar 7. Hama yang sering muncul di ruang pamer

(Sumber : Dean, David. 1994:74)

Debu rumah tangga adalah bahan yang kompleks, ini terdiri dari banyak senyawa berbeda termasuk serat tumbuhan dan hewan, pasir, limbah industri, hasil sampah pembakaran, dan hal lain yang dapat dibawa oleh arus udara. Tak perlu ditanyakan lagi, sudah pasti banyak dari komponen tersebut merusak koleksi. Partikel pasir bersifat abrasive menjadi serat tersedianya makanan bagi hama. Komponen kimiawi juga dapat menyebabkan persoalan serius dan kerusakan permanen pada permukaan objek koleksi (Dean, David. $1994: 72$ ).

Konsep preventif termasuk kondisi lingkungan di atas menjadi rujukan untuk mengetahui kondisi lingkungan di ruang pamer sehingga pengelolaan ruang pamer yang representative menjadi masukan untuk melakukan tindakan yang ketat dan tepat secara ilmiah serta komprehensif.

\section{METODE}

Untuk mendapatkan data kajian komodifikasi tata pamer dalam upaya preventif di Museum Adityawarman, perlu diperoleh data yang valid dan reliabel yang mampu dijadikan dasar untuk menjawab permasalahan kajian tersebut, maka dilakukan/dipilih teknik pengumpulan data yang meliputi pengamatan (observation) dengan menguji kelembapan ruang dan suhu pada ruang pameran lantai dua dengan mencatat hasil dari thermohydrometer, mengamati ruang lingkungan baik di dalam vitrin dan di luar vitrin, kemudian melakukan tahap analisis data (description) dengan maksud mengolah data dari hasil observation, dan terakhir tahap eksplanasi (explanation), merupakan tahap integrasi yang telah valid untuk menghasilkan inteprestasi dan eksplanasi terhadap permasalahan yang ada. 


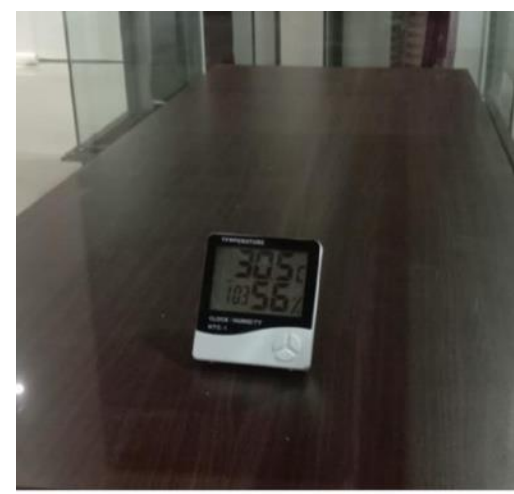

Gambar 8. Alat ukur Thermohydrometer

\section{HASIL KAJIAN}

\section{(Sumber : Pribadı)}

Bangunan gedung pameran utama Museum Adityawarman menempati lahan seluas 2,6 ha dengan luas ruangan utama lebih dari $365,76 \mathrm{~m} 2$ di lantai 2, berada di barat Kota Padang tepatnya di Kelurahan Belakang Tangsi, Kecamatan Padang Barat.

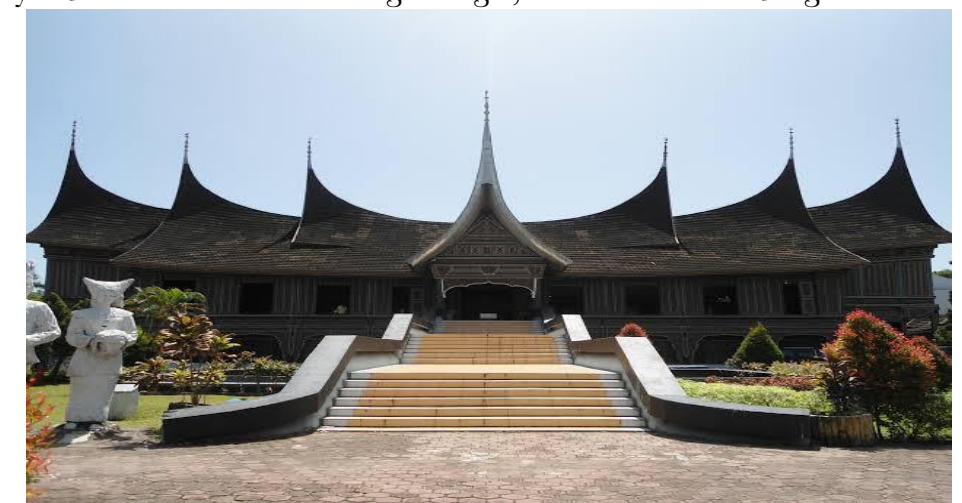

Gambar 9. Bangunan Menyerupai Rumah Adat Minangkabau (Sumber : Pribadi)

Ruang pamer memiliki jendela sebanyak 8 buah disisi barat dengan ukuran tinggi 3 meter dan lebar 2 meter dan untuk ruang di sisi timur sebanyak 6 buah dengan ukuran kurang lebih sama. Kondisi lantai dilapisi keramik ukuran $60 \mathrm{~cm}$ x $60 \mathrm{~cm}$ dengan tiang-tiang beton penyangga bangunan, tinggi plafon dibagian barat mencapai 5 meter tanpa ada penghalang plafon tambahan dan untuk bagian timur mencapai 3,5 meter, lebih rendah karena ada plafon ruang.

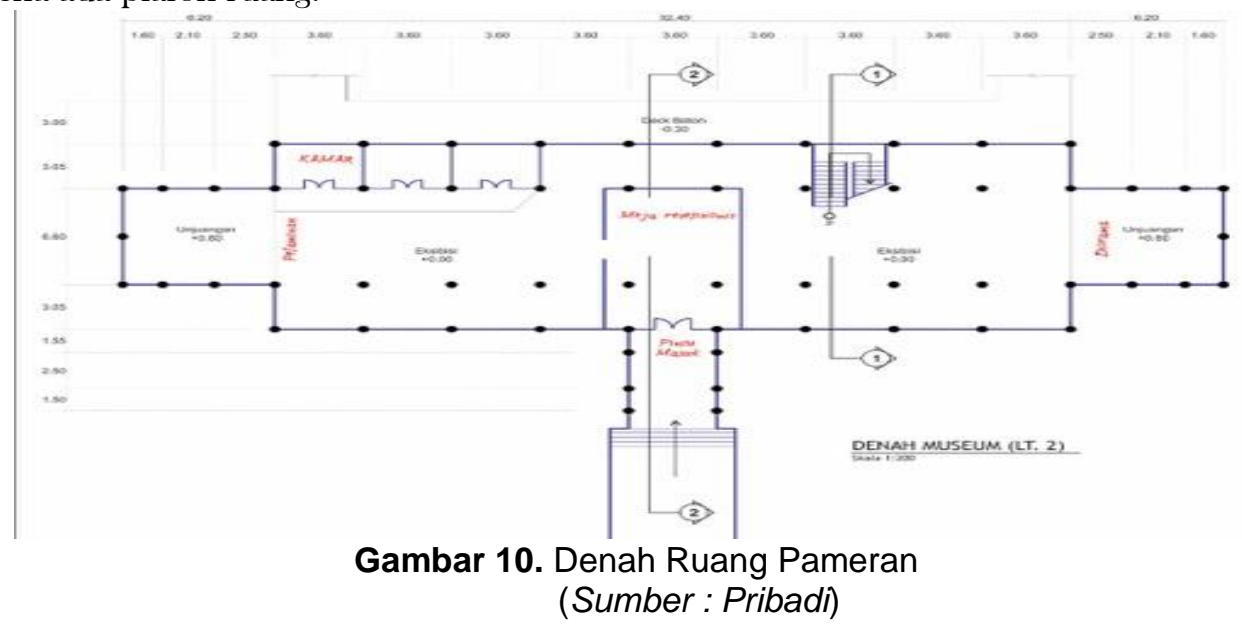


Bangunan ruang pamer menjadi salah satu bagian lapisan pelindung bagi pelestarian koleksi di ruang pamer terhadap faktor deteriorasi koleksi seperti serangga atau iklim cuaca yang selalu berubah, hal ini memaksa pengelola harus melakukan tindakan ruang untuk melindungi koleksi di dalam ruang pamer. Untuk mengetahui temperatur udara maksimum dan minimum dan kelembapan, ruang pameran sebelah barat di atur dengan kondisi ruang delapan jendela ditutup kaca dan dua jendela daun jendela tertutup rapat sepanjang hari. Untuk enam daun jendela lainnya terbuka saat jam operasional museum buka, jam buka operasional museum dari pukul 08.00 sampai 16.00 wib. Dengan ukuran ruang kurang lebih 160m2 mengandalkan satu penyejuk ruangan (AC) dengan kapasitas 2 Paard Kracht (PK) atau daya kuda, furnitur ruangan terdiri dari panel dengan ukurun hampir memanjang membelakangi dinding dan menutup jendela dan panel panjang yang berada di tengah ruangan.

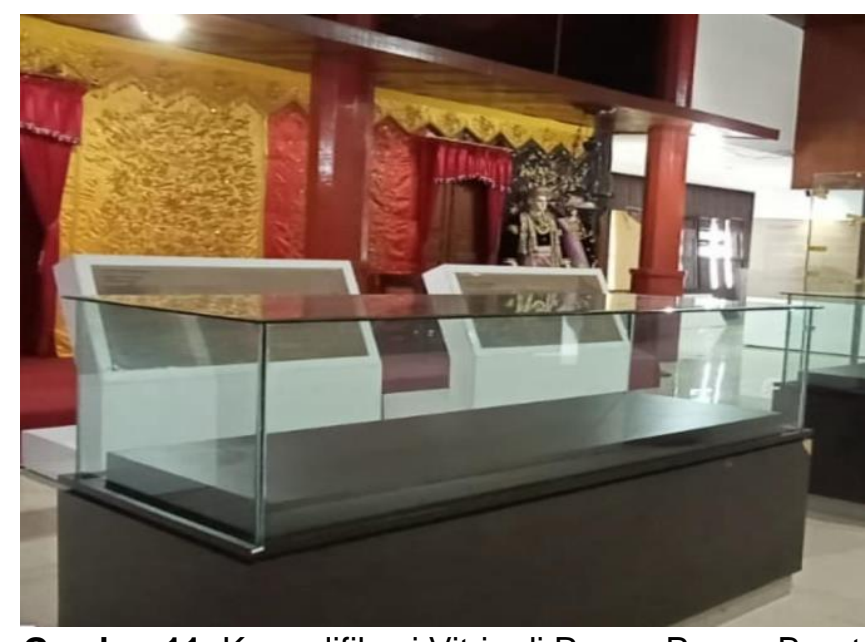

Gambar 11. Komodifikasi Vitrin di Ruang Pamer Barat (Sumber : Pribadi)

Bagian vitrin dilakukan perubahan pada tampilan kaca dengan mengganti dengan kaca bening berukuran $10 \mathrm{~mm}$ tanpa ada pintu, dengan pinggiran kaca di poles untuk menghindari sudut kaca atau sisi kaca yang tajam. Secara visual kondisi vitrin menjadi tertutup rapat dan sistem penguncian dengan menggunakan sistem berat beban kaca untuk menghindari resiko kehilangan. Penggunaan teknik kunci pada vitrin sudah bergeser penggunaannya dengan sistem yang berbeda, dulu menggunakan anak kunci atau memasang gembok. Sekarang penggunaan kaca dengan sistem hidrolik atau sistem baru lainnya dengan menggabungkan sensor gerak atau infrared dan alarm menjadi cara baru penampilan vitrin atau lemari pajangan di museum.

Waktu pengukuran dilaksanakan bulan januari dan pebruari 2021, hasil pengukuran suhu pada vitrin satu dan dua yang ada di sisi barat ruang pamer utama menunjukan angka di pagi hari $26,3^{\circ} \mathrm{C}-27,9^{\circ} \mathrm{C}$ dan siang hari $29,1^{\circ} \mathrm{C}-31,3^{\circ} \mathrm{C}$.

\begin{tabular}{|c|c|c|c|c|c|c|c|}
\hline & Waktu & Hari 1 & $\begin{array}{l}\text { Iabel } 1 \\
\text { Hari ? }\end{array}$ & nu di $R$ & 4 Sari 4 & Hari 5 & Hari 6 \\
\hline \multirow{2}{*}{ Vitrin 1} & 08.30 & $272^{\circ} \mathrm{C}$ & $277^{\circ} \mathrm{C}$ & $263^{\circ} \mathrm{C}$ & $276^{\circ} \mathrm{C}$ & $27.1^{\circ} \mathrm{C}$ & $272^{\circ} \mathrm{C}$ \\
\hline & 13.00 & $30,0^{\circ} \mathrm{C}$ & $30,3^{\circ} \mathrm{C}$ & $29,1^{\circ} \mathrm{C}$ & $30,1^{\circ} \mathrm{C}$ & $29,1^{\circ} \mathrm{C}$ & $30,0^{\circ} \mathrm{C}$ \\
\hline \multirow[t]{3}{*}{ Vitrin 2} & 08.30 & $27,1^{\circ} \mathrm{C}$ & $27,9^{\circ} \mathrm{C}$ & $26,4^{\circ} \mathrm{C}$ & $27,6^{\circ} \mathrm{C}$ & $27,2^{\circ} \mathrm{C}$ & $27,3^{\circ} \mathrm{C}$ \\
\hline & 13.00 & $30,1^{\circ} \mathrm{C}$ & $30,5^{\circ} \mathrm{C}$ & $29,2^{\circ} \mathrm{C}$ & $30,1^{\circ} \mathrm{C}$ & $29,1^{\circ} \mathrm{C}$ & $30,0^{\circ} \mathrm{C}$ \\
\hline & Waktu & Hari 7 & Hari 8 & Hari 9 & Hari 10 & Hari 11 & Hari 12 \\
\hline
\end{tabular}




\begin{tabular}{cccccccc}
\hline Vitrin 1 & 08.30 & $27,9^{\circ} \mathrm{C}$ & $27,5^{\circ} \mathrm{C}$ & $27,1^{\circ} \mathrm{C}$ & $27,9^{\circ} \mathrm{C}$ & $27,9^{\circ} \mathrm{C}$ & $27,8^{\circ} \mathrm{C}$ \\
& 13.00 & $30,4^{\circ} \mathrm{C}$ & $30,1^{\circ} \mathrm{C}$ & $30,2^{\circ} \mathrm{C}$ & $30,9^{\circ} \mathrm{C}$ & $31,0^{\circ} \mathrm{C}$ & $31,3^{\circ} \mathrm{C}$ \\
Vitrin 2 & 08.30 & $28,0^{\circ} \mathrm{C}$ & $27,7^{\circ} \mathrm{C}$ & $27,2^{\circ} \mathrm{C}$ & $28,0^{\circ} \mathrm{C}$ & $27,8^{\circ} \mathrm{C}$ & $27,7^{\circ} \mathrm{C}$ \\
& 13.00 & $30,5^{\circ} \mathrm{C}$ & $30,1^{\circ} \mathrm{C}$ & $30,3^{\circ} \mathrm{C}$ & $30,9^{\circ} \mathrm{C}$ & $30,7^{\circ} \mathrm{C}$ & $31,3^{\circ} \mathrm{C}$ \\
& & & &
\end{tabular}

Hasil pengukuran kelembapan di vitrin satu dan dua yang ada di sisi barat ruang pamer utama menunjukan angka di pagi hari 52\%- 67\% dan siang hari 50\%- $67 \%$.

\begin{tabular}{|c|c|c|c|c|c|c|c|}
\hline & \multicolumn{7}{|c|}{ Tabel 2. Kelembapan di Ruang Barat } \\
\hline & Waktu & Hari 1 & Hari 2 & Hari 3 & Hari 4 & Hari 5 & Hari 6 \\
\hline \multirow[t]{2}{*}{ Vitrin 1} & 08.30 & $67 \%$ & $54 \%$ & $53 \%$ & $59 \%$ & $61 \%$ & $66 \%$ \\
\hline & 13.00 & $54 \%$ & $51 \%$ & $50 \%$ & $58 \%$ & $61 \%$ & $61 \%$ \\
\hline \multirow[t]{3}{*}{ Vitrin 2} & 08.30 & $71 \%$ & $59 \%$ & $59 \%$ & $63 \%$ & $58 \%$ & $68 \%$ \\
\hline & 13.00 & $57 \%$ & $56 \%$ & $55 \%$ & $61 \%$ & $58 \%$ & $63 \%$ \\
\hline & Waktu & Hari 7 & Hari 8 & Hari 9 & Hari 10 & Hari 11 & Hari 12 \\
\hline \multirow[t]{2}{*}{ Vitrin 1} & 08.30 & $64 \%$ & $53 \%$ & $58 \%$ & $57 \%$ & $55 \%$ & $52 \%$ \\
\hline & 13.00 & $62 \%$ & $59 \%$ & $53 \%$ & $51 \%$ & $47 \%$ & $45 \%$ \\
\hline \multirow[t]{2}{*}{ Vitrin 2} & 08.30 & $67 \%$ & $67 \%$ & $63 \%$ & $62 \%$ & $62 \%$ & $60 \%$ \\
\hline & 13.00 & $65 \%$ & $64 \%$ & $58 \%$ & $56 \%$ & $54 \%$ & $51 \%$ \\
\hline
\end{tabular}

(Sumber : Hasil Pengukuran)

Untuk ruang pameran sebelah timur dengan kondisi ruang enam jendela di coba ditutup dengan kaca dan satu jendela dengan daun jendela tertutup rapat sepanjang hari dan lima daun jendela lainnya terbuka saat jam operasional museum buka.

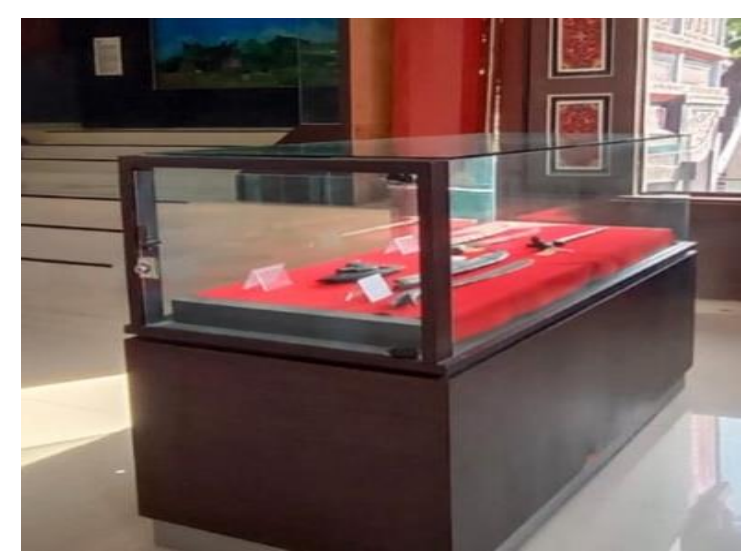

Gambar 12. Vitrin di Ruang Pamer Timur (Sumber : Pribadi)

Dengan ukuran ruang kurang lebih $160 \mathrm{~m} 2$ mengandalkan tiga penyejuk ruangan (AC) dengan kapasitas 2 PK namun dengan dua kondisinya kurang baik, furnitur ruangan terdiri dari satu panel panjang yang berada di tengah ruangan dan 15 vitrin tinggi dan dua vitrin sedang, pengukuran hanya dilakukan pada vitrin pada Gambar 15 dengan asumsi ukuran vitrin sama dengan dua vitrin sebelumnya di bagian barat.

Tabel 3. Suhu di Ruang Timur 


\begin{tabular}{cccccccc}
\hline & Waktu & Hari 1 & Hari 2 & Hari 3 & Hari 4 & Hari 5 & Hari 6 \\
Vitrin 1 & 08.30 & $32,9^{\circ} \mathrm{C}$ & $29,0^{\circ} \mathrm{C}$ & $29,3^{\circ} \mathrm{C}$ & $29,9^{\circ} \mathrm{C}$ & $29,9^{\circ} \mathrm{C}$ & $30,0^{\circ} \mathrm{C}$ \\
Vitrin 2 & 13.00 & $32,4^{\circ} \mathrm{C}$ & $31,8^{\circ} \mathrm{C}$ & $32,3^{\circ} \mathrm{C}$ & $32,5^{\circ} \mathrm{C}$ & $32,5^{\circ} \mathrm{C}$ & $32,1^{\circ} \mathrm{C}$ \\
& 08.30 & $33,1^{\circ} \mathrm{C}$ & $29,4^{\circ} \mathrm{C}$ & $30,6^{\circ} \mathrm{C}$ & $30,2^{\circ} \mathrm{C}$ & $30,0^{\circ} \mathrm{C}$ & $30,2^{\circ} \mathrm{C}$ \\
& 13.00 & $32,3^{\circ} \mathrm{C}$ & $33,9^{\circ} \mathrm{C}$ & $32,5^{\circ} \mathrm{C}$ & $32,5^{\circ} \mathrm{C}$ & $32,5^{\circ} \mathrm{C}$ & $32,5^{\circ} \mathrm{C}$ \\
Vitrin 1 & 08.30 & $29,4^{\circ} \mathrm{C}$ & $29,3^{\circ} \mathrm{C}$ & $29,4^{\circ} \mathrm{C}$ & $29,4^{\circ} \mathrm{C}$ & $29,7^{\circ} \mathrm{C}$ & $29,3^{\circ} \mathrm{C}$ \\
& 13.00 & $32,2^{\circ} \mathrm{C}$ & $31,3^{\circ} \mathrm{C}$ & $32,4^{\circ} \mathrm{C}$ & $32,3^{\circ} \mathrm{C}$ & $32,1^{\circ} \mathrm{C}$ & $31,7^{\circ} \mathrm{C}$ \\
Vitrin 2 & 08.30 & $35,5^{\circ} \mathrm{C}$ & $30,6^{\circ} \mathrm{C}$ & $30,6^{\circ} \mathrm{C}$ & $29,6^{\circ} \mathrm{C}$ & $30,5^{\circ} \mathrm{C}$ & $29.6^{\circ} \mathrm{C}$ \\
& 13.00 & $32,0^{\circ} \mathrm{C}$ & $31,4^{\circ} \mathrm{C}$ & $32,5^{\circ} \mathrm{C}$ & $32,6^{\circ} \mathrm{C}$ & $32,3^{\circ} \mathrm{C}$ & $31,8^{\circ} \mathrm{C}$ \\
& & & & & & &
\end{tabular}

Hasil pengukuran suhu di vitrin satu dan dua yang ada di sisi timur ruang pamer utama menunjukan angka di pagi hari $29,3^{\circ} \mathrm{C}-35,5^{\circ} \mathrm{C}$ dan siang hari $31,3{ }^{\circ} \mathrm{C}-32,5^{\circ} \mathrm{C}$. Pada hari ketujuh satu daun jendela yang menghadap timur ditutup karena kondisi suhu tinggi di pagi hari di dalam vitrin mencapai $35,5^{\circ} \mathrm{C}$.

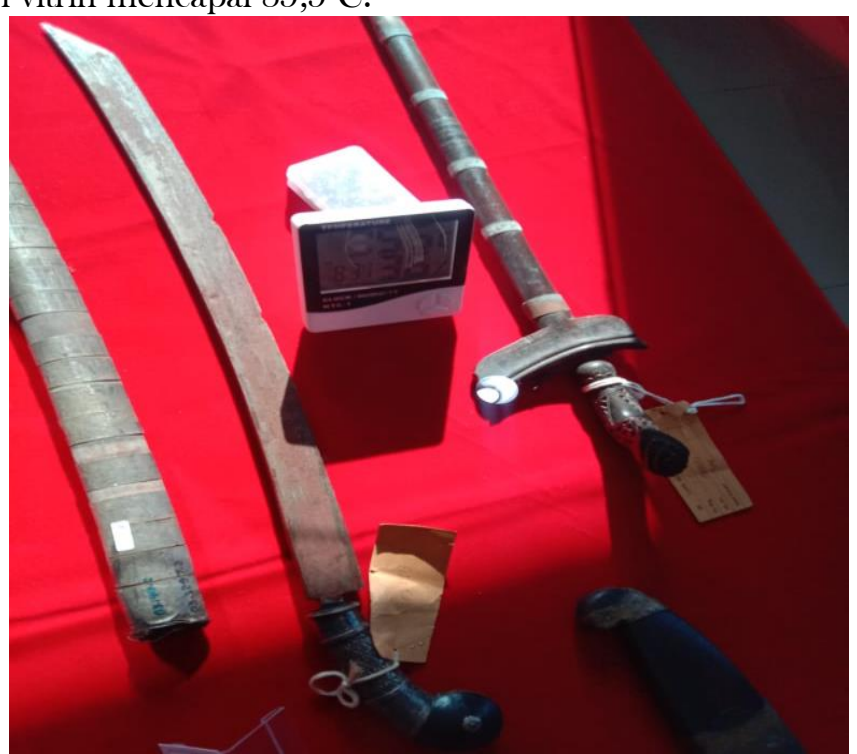

Gambar 13. Suhu di dalam vitrin mencapai $35,5^{\circ} \mathrm{C}$

(Sumber : Pribadi)

Hasil pengukuran kelembapan di vitrin satu dan dua yang ada di sisi timur ruang pamer utama menunjukan angka di pagi hari $38 \%-61 \%$ dan siang hari $50 \%-67 \%$. Pada hari ketujuh satu daun jendela yang menghadap timur dengan kondisi ditutup karena kelembapan yang rendah di pagi hari mencapai $38 \%$.

\begin{tabular}{|l|c|c|c|c|c|c|c|}
\hline & \multicolumn{8}{|c|}{ Tabel 4. Kelembapan di Ruang Timur } \\
\hline Vitrin 1 & 08.30 & $50 \%$ & $51 \%$ & $51 \%$ & $54 \%$ & $57 \%$ & $61 \%$ \\
\hline & 13.00 & $51 \%$ & $53 \%$ & $51 \%$ & $54 \%$ & $57 \%$ & $58 \%$ \\
\hline Vitrin 2 & 08.30 & $50 \%$ & $47 \%$ & $45 \%$ & $50 \%$ & $53 \%$ & $57 \%$ \\
\hline
\end{tabular}




\begin{tabular}{|c|c|c|c|c|c|c|c|}
\hline & 13.00 & $56 \%$ & $49 \%$ & $49 \%$ & $52 \%$ & $53 \%$ & $55 \%$ \\
\hline & Waktu & Hari 7 & Hari 8 & Hari 9 & Hari 10 & Hari 11 & Hari 12 \\
\hline \multirow[t]{2}{*}{ Vitrin 1} & 08.30 & $51 \%$ & $55 \%$ & $52 \%$ & $50 \%$ & $54 \%$ & $54 \%$ \\
\hline & 13.00 & $46 \%$ & $54 \%$ & $50 \%$ & $52 \%$ & $56 \%$ & $58 \%$ \\
\hline \multirow[t]{2}{*}{ Vitrin 2} & 08.30 & $38 \%$ & $50 \%$ & $46 \%$ & $45 \%$ & $49 \%$ & $60 \%$ \\
\hline & 13.00 & $51 \%$ & $51 \%$ & $46 \%$ & $48 \%$ & $52 \%$ & $54 \%$ \\
\hline
\end{tabular}

Perbedaan suhu dan kelembapan yang berbeda di ruang barat dan timur menimbulkan gangguan lingkungan yang berbeda di luar vitrin selain volume ruang yang lebih besar di sebelah barat, plafon yang lebih tinggi di barat sering dijumpai lebih banyak serangga seperti lebah kayu (Xylocopa Virginica), tapi bukan faktor utama dan perlu dilakukan kajian lebih lanjut penyebab kehadiran serangga tersebut, serangga ini mudah dikenali dengan warna kuning emas yang dominan di punggung atau juga berwarna hitam dan memiliki garis hitam dan kuning di ekornya. Walaupun jendela sudah tertutup rapat bisa saja masuk dari celah dinding kayu di ruang barat yang terbuka sepanjang hari. Tapi dengan adanya pelindung kaca jendela tidak dijumpai lagi burung yang masuk ke ruang barat ketika jendela tidak tertutup kaca pada waktu pengamatan.

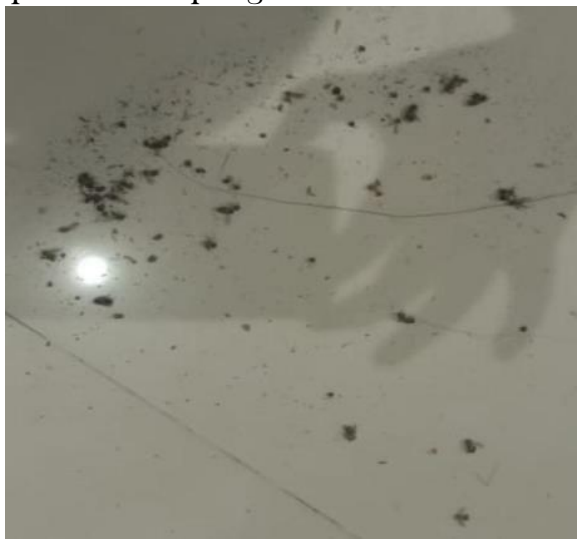

\section{Gambar 14. Serangga Lebah Kayu di Ruang Pamer Barat (Sumber photo: Pribadi)}

Hasil pengamatan di dalam vitrin ruang pamer barat setelah tiga puluh hari belum ditemukan serangga seperti laba-laba atau sejenis hewan berbuku-buku yang digolongkan ke dalam ordo Araneae, kemampuan vitrin dengan kaca lebih tebal dan rapat mempunyai kemampuan lebih baik dari serangan serangga. Berbeda dengan vitrin sebelah timur ditemukan lebih cepat serangga di dalam vitrin, kondisi vitrin sebelum diamati telah dilakukan pembersihan di dalam interior virtrin terlebih dahulu.

\section{KESIMPULAN}

Dari hasil pengamatan dan tindakan ruang maka bisa disimpulan bahwa untuk ruang pameran sebelah barat mempunyai indikator yang lebih baik dengan ruang pameran timur dengan situasi sebagai berikut, kondisi ruang pamer barat lebih sedikit mendapatkan sinar matahari khususnya di pagi hari, dengan menunjukan angka pengukuran di pagi hari $26,3^{\circ} \mathrm{C}$ - 27,9 $9^{\circ} \mathrm{C}$ di dalam vitrin selama 12 hari pengamatan ruang dan kondisi panil yang menutupin dua jendela sepanjang hari membantu menghalangi udara masuk ke ruang pamer. Sedangkan untuk di timur mengalami peningkatan dengan menunjukan angka di pagi hari di dalam vitrin $29,3{ }^{\circ} \mathrm{C}-35,5^{\circ} \mathrm{C}$ menjadikan ruang timur suhu udara yang lebih tinggi. Sinar matahari yang secara terus menerus masuk ke ruang timur dapat mengancam kondisi koleksi yang ada, 
pemasangan kaca yang ada belum dapat membantu untuk menyaring sinar UV dari matahari masuk keruangan.

Kelembapan di ruang pamer barat menunjukan angka di pagi hari 52\%- 67\% di dalam vitrin, hal ini mengundang serangga yang lebih beragam masuk ke dalam ruang pameran. Perlu upaya lebih lanjut untuk melakukan penelitian penyebab adanya serangga, apakah karena banyaknya celah dinding kayu yang terbuka atau perlunya dilakukan pelapisan dinding kayu bagian dalam yang lebih baik di ruang pamer barat atau penggunaan desikan yang belum maksimal. Kemudian kelembapan di ruang timur menunjukan angka di pagi hari 38\%- 61\% di dalam vitrin, kelembapan yang rendah sangat membahayakan kepada struktur koleksi yang ada, bisa menyebabkan koleksi organik menjadi retak dan rapuh.

Untuk performa vitrin sebelah barat dengan kaca lebih tebal dari timur membuat keamanan koleksi lebih baik dan layak untuk menyajikan koleksi organik karena lebih sedikit celah yang menyebabkan masuknya hama atau polutan bahkan serangga ke dalam vitrin, namun perlu dilakukan pemikiran ulang dalam tindakan perawatan secara periodik karena ruang pameran tetap memiliki jangka waktu pamer yang lebih lama yaitu tiga hingga lima tahun sehingga perlu waktu untuk perawatan terhadap vitrin.

Kenyamanan pengunjung di ruang pamer barat cukup baik di pagi hari dan kurang nyaman untuk siang hari ini berdasarkan standar kenyamanan ruang internasional ASHRAE 55-92, untuk kenyamanan pengunjung di ruang pamer timur menunjukan hasil kurang begitu baik pada pagi dan siang hari.

Dari kesimpulan tersebut maka perlu dipikirkan proses-proses komodifikasi tata pamer seperti bagaimana cara menutup jendela bangunan yang lebih baik untuk menghindari sinar ultra violet (UV) masuk ke ruang pameran secara berlebihan dengan tentunya dengan mempertimbangkan struktur bangunan tampak dari luar, kemudian pemasangan dehumidifier di ruang pamer baik barat dan timur diperlukan untuk mengatur kelembapan ruang dan pemasangan data logger di setiap ruang. Memperbaiki sistem pendingin ruang pamer di bagian timur menjadi hal yang mendesak untuk dilakukan, terakhir upaya pencatatan dan penggunaan semua alat ukur seperti lightmeter, uv meter, thermohydrometer, dan lainnya harus menjadi pekerjaan rutin yang dilakukan pengelola ruang pamer. Semua ini dilakukan sebagai hasil komodifikasi sehingga ruang pamer museum dapat di terima masyarakat sebagai ruang publik yang menarik.

Terakhir, hasil penelitian ini masih bersifat sementara dan tentunya masih memiliki kekurangan dalam inteprestasi dan eksplanasi masalah yang ada, banyak kajian yang perlu dilakukan terutama proses dan tahapan pekerjaan di ruang pamer seperti alur pengunjung, tingkat kepuasan pengunjung, sistem pencahayaan, rancangan vitrin sesuai antropometri, konsep pameran yang terintegrasi, dan lainnya untuk mendapatkan hasil yang lebih baik.

\section{DAFTAR PUSTAKA}

\section{Buku :}

Barker, Chris. Cultural Studies : Teori dan Praktek. Yogyakarta: Bentang. 2005

Ching, Francis DK. Arsitektur Bentuk, Ruang, dan Tatanan, Jakarta, 2018.

Dean, David. Museum Exhibition : Theory and Practice, Routledge, London, 1994.

Sutaarga, Moh Amir, Pedoman Penyelenggaraan Dan Pengelolaan Museum.

Departemen Pendidikan dan Kebudayaan, Jakarta 1997/1998

McLean, K. Planning for People in Museum Exhibitions. Washington:

Association of Science -Technology Centers. 1993 
Qodratilah, Meity Taqdir. Kamus Bahasa Indonesa Untuk Pelajar, Jakarta, Badan Pengembangan dan Pembinaaan Bahasa, 2011

Tester, Keith. Immor/t]alitas Media. Yogyakarta: Penerbit Juxtapose. 2009

Thahjopurnomo, R. Konsep Penyajian Museum. Jakarta, Direktorat Permuseuman, 2011. Yulita, Ita. dkk. Konservasi Koleksi Tekstil, Museum Nasional, Jakarta, 2020.

\section{Jurnal :}

Aegeson T.H. Market value: 5 steps to an effective museum marketing plan. Museum News, July/August 1999

Herle, A. Anthropology Museums and Museum Anthropology. In The Cambridge Encyclopedia of Anthropology (eds) F. Stein, S. Lazar, M. Candea, H. Diemberger, J. Robbins, A. Sanchez \& R. Stasch. 2016.

Purnomo, Agung. Basnendar Herryprilosadoso, Ranang Agung Sugihartono.

Alternatif Desain Vitrin Untuk Museum Radyapustaka, Volume 3 No. 2.

Fakultas Seni Rupa dan Desain ISI Surakarta. 2012

Rozaq, M. Kholid Arif, Vicky Ferdian Saputra, Mikke Susanto Konservasi Preventif

Lukisan Koleksi Museum. Jurnal Tata Kelola Seni Vol 5 No. 2.

Yogyakarta. 2019

Santoso, Eddy Imam, Kenyamanan Termal Indoor Pada Bangunan Di Daerah Beriklim

Tropis Lembab, Indonesia Green Technology Journal. Surabaya. 2012

Tiurman, Aninda Renata dan Ali Akbar. Preservasi Koleksi Di Ruang

Penyimpanan Museum Nasional, Arkeologi Fakultas Ilmu Budaya.

Depok. 2013

Wulandari, Anak Agung Ayu. Dasar-dasar Perencanaan Interior Museum, Jakarta, Jurnal Humaniora Vol.5 No. 1, 2014 